\title{
HOW DIGITALIZATION CHANGES THE WORKPLACE
}

\author{
Anamarija Cijan \\ Faculty of Economics, University of Ljubljana, Slovenia \\ am.cijan@gmail.com \\ Lea Jenič \\ Faculty of Economics, University of Ljubljana, Slovenia \\ leja.jenic@gmail.com
}

Amadeja Lamovšek

Faculty of Economics, University of Ljubljana, Slovenia

amadeja.lamovsek@gmail.com

Jakob Stemberger

Faculty of Economics, University of Ljubljana, Slovenia

stemberger.jakob@gmail.com

\begin{abstract}
This article examines how digitalization affects the workplace. Digitalization has been changing organizations from the discovery of the internet forward. Nowadays people cannot imagine business or their personal lives without digital technologies. Digitalization has created many challenges as well as excellent opportunities for organizations. Most existing studies examined the role of digitalization on business performance and worker productivity. We focus specifically on job satisfaction, work/life balance, and worker autonomy as three under-researched areas of academic inquiry. We suggest that digitalization improves job satisfaction, blurs work/life balance, and promotes more worker autonomy. This research is based on answers collected with an online survey of 98 individual employees, working professionals across industries and disciplines. We analyze gathered data with one-sample t-tests and support all three hypotheses. Findings from the research can help managers better understand the importance and the effects of the digitalization. Because digitalization at work brings challenges and as well opportunities, it is important for managers to understand them completely in order to eliminate the risks and increase the favorable effects.
\end{abstract}

Keywords: digitalization, workplace, changes, autonomy, work/life balance

\section{INTRODUCTION}

Digitalization has become one of the most important topics. Today, digital assets can be found in most (if not all) organizations (Kuusisto, 2015). Labor markets and work processes have transformed enormously since information and communication tech- nologies have emerged (Castells, 2010). The effects of new technologies have been investigated since their beginning in the 1960s. Fernández-Macías (Eurofound 2015) outlined four major implications of digitalization on organizations. The first is changes of tasks and occupations as new technologies create new job roles and new processes. The second 
change involves work conditions, because with the implementation of technology, more physical, psychological, and environmental requirements appeared. Furthermore, there are significant changes in employment conditions (e.g., the contractual and social conditions of the work). Lastly, changes occurred also in industrial relations, for example, in how employers and employees organize their relations and settle their disputes. The topic is important for managers because they need to know how employees feel about digitalization and how it impacts their satisfaction and work/life balance, and also whether it increases the level of autonomy. If managers have proper knowledge, they can actually eliminate the risks and allow employees to enjoy its benefits.

We conducted research on this topic because when reviewing the literature we found that although many studies have investigated this topic, most of them focused on how digitalization impacts business performance and worker productivity (Kuusisto, 2015). They were less interested in employee satisfaction, and effects on work/life balance and worker autonomy, which were our main areas of focus. In the research that did focus on the three mentioned topics, some of the results were unclear or even two-sided. For example, some studies on worker autonomy and its connection to digitalization are divergent. Gerten, Beckmann, \& Bellmann (2018) found out that digitalization actually enables employers to monitor employees even more, whereas Aral \& Weill (2007) stated that digitalization provides more worker autonomy. Because of these inadequacies, we wanted to analyze the hypotheses ourselves.

This study a) explores how digitalization affects job satisfaction, work/life balance, and worker autonomy and $\mathrm{b}$ ) tests the proposed connection in the working environment. Our contribution empirically examines the influence of digitalization on a sample of Slovenian employees in different organizations.

The paper is structured as follows. First, we present the findings from the reviewed literature and previous studies. Second, we present the methodology used, the analysis, and the results. Lastly, we discuss the results and present the implications and future research.

\section{THEORETICAL BACKGROUND}

Digitalization is a term that describes the phenomenon of adopting digital technologies in business and society. Furthermore, the term also covers the affiliated changes in the connectivity of individuals, organizations, and objects (Urbach \& Röglinger, 2019). Digitalization is creating keen changes in the world of work. It all started in 1969 when the internet was deployed. Castells (2010) stated that the key feature of wireless communication is not mobility but perpetual connectivity. Digitalization, meaning the growing use of information and communication technology in every area of our lives, has impacted all levels of our society and influenced the way we do business. Digitalization has created many challenges as well as excellent opportunities in the workplace and in life in general. The world is concerned with the risk of technological unemployment, the quality and conditions of work, the risk of even greater economic inequality, etc. On the other hand, there are many new opportunities with the rise of new jobs and new markets, rising environmental sustainability, improving ergonomics and the safety of production processes, etc. (Governo Italiano, n.d.).

Digitalization has increased the tempo of daily life. We live in "sped-up society," with a faster pace through the day, fewer pauses, more multitasking, and more time pressures. Most of it is directly connected with information and communication technology (ICT). ICT actually allows us to do tasks and activities easier and faster, but nowadays people have more and more activities. If there are more activities, less time can be spent on each, so people feel more pressured (Sullivan \& Gershuny, 2018). One of the biggest impacts of digitalization on organizations is that information has become more accessible and transparent, which allows organizations to share more information with all employees - even those at lower levels of the hierarchy (Kuusisto, 2015). This easy accessibility resulted in increased worker productivity and in greater demands at work and at home (Chesled, 2010). The European Social Observatory (OSE) carried out an exploratory study on the impact of digitalization on the content and quality of jobs. The results showed that new technologies have an impact on the way people work. For around $66 \%$ of the surveyed workers, the digitization process resulted in an 
intensification of work and to some increase in the pace of work (Peña-Casas et al, 2018). Information and communication technology enables employees to focus more on complex tasks that require human knowledge, because secondary, repetitive tasks can be done automatically by computer. Studies have also suggested that digitalization enables greater productivity and efficiency (Vuori, Helander \& Okkonen, 2018). Furthermore, digitalization has caused rapid and even disruptive changes in most companies and future competitive environments. New models of organizations and businesses (e.g., Airbnb) are emerging, and traditional companies must reconsider their structures, roles, and strategies to achieve their new business goals. Kettunen \& Laanti (2017) viewed new future competitive organizations as agile, sustainable, and more fundamentally software-based. Nowadays people cannot imagine business or their personal lives without digital technologies. With new business models and strategies, job roles are often reorganized, which can lead to alteration of satisfaction, work/life balance, and worker autonomy.

\subsection{Job satisfaction}

Job satisfaction can be perceived as one's total feeling about their job and the views they have toward multiple aspects of their job, as well as an approach and perception that could affect the degree of correlation between an individual and their employer. An individual with high job satisfaction appears to have generally positive views, and one who is dissatisfied appears to hold negative views toward their job (Lumley et al., 2011).

Ratna \& Kaur (2016) defined job satisfaction as "favorableness or un-favorableness with which the employee views his work." It resembles the balance between the benefits of the job and one's assumption of them. An individual's job environment, i.e., workplace, is a crucial element of one's life because unarguably job satisfaction affects one's life satisfaction as a whole. Therefore, job satisfaction is a consequence of multiple beliefs of an employee. These beliefs are associated with the job and such distinct factors as wages, working conditions, employer's fair treatment, employer's supervision, prompt settlement of grievances, and social or human relation with the job. However, it could be argued that in line with a more comprehensive approach, inter- and intra-personal factors need to be included before a thorough understanding of job satisfaction can be reached. These factors are one's health, age, and desire. Moreover, one's social status, relationships, work, and away-from-work activities importantly influence job satisfaction (Ratna \& Kaur, 2016).

From its beginnings, information technology has been a vital aspect in business. IT was and is still used to reduce costs, improve customer service, and enhance operations and communications (Ratna \& Kaur, 2016). Because job satisfaction is closely associated with job turnover and life satisfaction, it is a crucial benchmark for the success of any company. The use of new technologies, e.g., the internet, virtual reality, computer-aided manufacturing, and expert systems, offers organizations an edge. They can result in offering high-quality products, providing more valuable services for customers, and making employees "work smarter." Organizations that have achieved considerable benefits from the use of new technologies have human resource management methods supporting the use of technology to construct high-performance work systems. In order to support and enhance employees' use of new technologies, work, reward systems, programs, and training need to be rearranged (Ratna \& Kaur, 2016).

Ratna \& Kaur (2016) researched the impact of information technology on job related factors, including job satisfaction. They discovered that after the implementation of new technologies, $23 \%$ of employees are more devoted, $20 \%$ believe their work is acknowledged, $20 \%$ think they can manage several tasks at once, $19 \%$ presume that there are better chances at work, and $18 \%$ believe that they are given all the resources they need in order to work. Moreover, Ratna \& Kaur found that of five related factors, technology most strongly affects employees' performance, followed by job satisfaction.

Sempane, Rieger \& Roodt (2002) stated that "research shows that job satisfaction does not come about in isolation, as it is dependent on organizational variables such as structure, size, pay, working conditions and leadership, which represent the organizational climate." Turnover could increase if job satisfaction is missing and other career opportunities arise (Lumley et al., 2011). 
Lumley et al. (2011) found that if managers want to build a working environment that encourages people to stay with their respective employers, they need to review current pay practices with the objective to offer fair pay, offer challenging and meaningful work tasks, and encourage positive coworker relationships.

Gallie (2013) found that workers treasure nonwage features of job quality. That is shown by increasing efforts at the national as well as the international levels to pursue higher-quality jobs. Discretion is strongly correlated with employees' drive and job satisfaction according to multiple measures of psychological well-being. A high work pace can lead to negative psychological outcomes, including stress (Salvatori, Menon \& Zwysen, 2018).

As a consequence of rapid growth of computer use across European countries in the last 20 years (Salvatori, Menon \& Zwysen, 2018), one can think that employee job satisfaction grew, to some extent, due to use of new technology, and will continue to do so as new technologies come into mainstream business activities.

\subsection{Work-life balance}

As defined by Lockwood (2003), work/life balance is "a state of equilibrium in which the demands of both a person's job and personal life are equal." Moreover, one could argue that work/life balance is a state of equilibrium in which someone's priorities regarding employment and personal lifestyle are achieved (Ratna \& Kaur, 2016).

A couple of versions of the work/life balance viewpoint can be analyzed. Firstly, the employee perspective focuses on how successfully an employee can manage work obligations and personal/family obligations. Secondly, employers should be motivated to provide a supportive company culture in which employees are able to focus on their jobs while at work (Lockwood, 2003).

In previous years, many potentially labor-saving technological devices have been developed. However, it is questionable whether they increase or decrease workload and stress. It is generally known that technology makes it easier to work more efficiently and smoothly. On the other hand, having access to per- sonal computers while at home is a dual-edged sword. The advantage of the use of technology in spare time is clear; an individual can arbitrarily decide whether to work for the job while at home (e.g., prepare some reports, presentations, analyses, etc.) (Ratna \& Kaur, 2016). Moreover, the main advantage that is incurred is the flexibility that mobile technology can offer. That means that workers can freely choose when, where, and how they will work (Towers et al., 2006).

However, it also means that it is not possible to get away from work, because technology enables us to work remotely (Ratna \& Kaur, 2016).

According to Hill et al. (1996) and Towers et al (2006) there is a negative impact on family life as working hours increase, i.e., flexibility has blurred the boundaries between work and family life. In addition, digitalization might increase expectations; colleagues could expect that staff can always be available to do work, which might increase stress level (Towers et al., 2006).

As noted by Jääskeläinen (2015), several interviews pointed out that it is difficult to control working hours when able to work outside the workplace. When working around the clock, someone can feel more stressed. It is necessary for someone to possess a certain ability to set limits themselves, e.g., not checking office mail while off duty. Results have shown that the development of new technologies has induced worries among employees; this depends on divisions between generations (the polarization of workforce). It also depends on the profession in which someone is engaged, e.g., healthcare professionals and higher education teachers have said that the use of technology can create stress.

Derks et al. (2014) investigated the impact of the use of work-related smartphones on daily recovery from work-related efforts. They discovered that being connected to work while at home means that an individual has less opportunity to recover from workrelated efforts. This means that smartphone users have not successfully dealt with recovery activities.

It can be said that smartphones increase the flexibility of an employee; however, it means that work/life balance can be blurred. The most important factor is the way someone deals with it; as previously stated, it is important to set oneself limits, 
e.g., working after finishing the work day is not desirable. A smartphone increases the flexibility of an employee but facilitates working long hours, with a risk of disturbed work/home balance at the same time. Technology in itself is neither a demand nor a resource; what matters is how we deal with it (Derks \& Bakker, 2010).

Our study suggests that work/life balance is blurred, meaning that employees find it hard to switch off from work when they are at home. Moreover, we argue that it is difficult for an individual to control the amount of time spent using technology for work purposes. Therefore, we expect that digitalization blurs the boundaries between job and personal life.

\subsection{Worker autonomy}

Employee autonomy or job autonomy refers to the amount of control employees have over their job situations. In other words, worker autonomy is defined as how much freedom, discretion, and independence employees have in scheduling their working tasks and defining the process when completing them (Hackman \& Oldham, 1976).

Our research focuses on autonomy, which is formally given to the employees by organizations themselves. Specifically, we are interested in autonomy in connection with conducting and planning the work; for example, the freedom an employee has when carrying out different activities without the approval of a supervisor. This autonomy is also referred to as "strategic autonomy" (Globocnik \& Salomo, 2015).

From a theoretical point of view, technology can have two different types of effect on the working environment. Firstly, worker autonomy can be increased due to the use of modern information and communication technologies (Aral \& Weill, 2007). For example, cloud computing is a large factor in centralized information storage and decentralized information access, which gives employees the possibility of faster communication and easier sharing of work-related knowledge from different places and in real time (European Economic and Social Committee, 2017). Similarly, Gibbs (2017) concluded that innovative ICT contributes to a new helpful work organization which includes more autonomy in terms of working place, working time, or accomplishing different tasks. Furthermore, Mazidabadi-Farahani (2011) found that technology and digitalization empower employees of different organizations. Mazidabadi-Farahani connected this result to IT with 95\% probability. Lastly, Ardalan (2011) pointed out that technology (mostly computer use) contributes to an increase in employee knowledge as well as more effective transfer of messages and orders within an organization. All this is possible due to IT and without the need for traditional management or organizational structures.

On the other hand, the fast expansion of ICT use among employees makes monitoring of professional activities easier, and therefore a greater degree of centralization more possible. This is especially possible with the use of data storage and digital devices which make permanent accessibility possible, because both provide many opportunities for organizations to monitor their employees (Gerten, Beckmann, \& Bellmann, 2018). All this results in lower levels of individual autonomy for employees, because intensive control contributes to changes made in their behavior at work so that they can better meet corporate goals. This was also confirmed by Gerten, Beckmann and Bellmann (2018), who showed that use of modern technologies increases monitoring activities among employees. Similarly, Tafti, Mithas and Krishnan (2007) found that firms are increasingly using informational technology to increase control over employees in terms of time tracking, monitoring IT use, and proficiency evaluation. For example, with the help of ICT, managers can easily access information on their employees' locations (Krause, 2016).

Regarding the connection between autonomy and digitalization in the workplace, in some cases, both autonomy and monitoring can increase simultaneously, as was proven by Gerten, Beckmann and Bellmann (2018) They provided evidence that ICT can promote both decentralization and centralization; they discovered that the use of ICT caused an increase in worker autonomy for employees (but only for those working in high positions, for example, managers) but also an increase in monitoring of employees in the organization.

To conclude, much research has been done on the topic of technology and worker autonomy, but the findings are not clear. Therefore, we studied 
whether digitalization promotes more worker autonomy, more monitoring, or a mix of both. Because most economic studies of ICT's impact on organizations suggests that digitalization promotes worker autonomy, we used this information as a basis when developing our third hypothesis.

Hypothesis 1: Digitalization improves job satisfaction.

Hypothesis 2: Due to digitalization, work/life balance blurs.

Hypothesis 3: Digitalization promotes more worker autonomy

\section{METHODS}

\subsection{Sample and data collection}

This study was formulated based on a quantitative approach. First, we carried out desktop research which included a review of the literature. Based on different studies, we developed an online survey to determine how digitalization changes the workplace. We developed the survey using online platform 1KA (called also One Click Survey). The survey was distributed through email, Facebook, and Linkedin. The convenience sampling method was used because the survey was distributed mostly among close associates (friends, family members, co-workers, etc.). The survey was available from January 8, 2019 to January 29, 2019.

The sample for this study consisted of students and workers, mostly from Slovenia. We received 98 responses ( $45 \%$ male and $55 \%$ female). Most ( $78 \%$ ) were between the ages of 20 and 41; the second largest group (19\%) was people aged 41-60.

The survey contained 11 questions (constructs), which included 47 variables (items). Average duration of the survey was 5 minutes 41 seconds. The first question analyzed the connection of the individual workplace with digitized tasks. This was done with a seven-point Likert-type scale ( $1=$ almost never, $7=$ almost always). The question was taken from Salvatori, Menon \& Zwysen. (2018). The second, third, and fourth questions used a five-point Likert-type scale (1 = strongly disagree, 5 = strongly agree) and measured the impacts of digitalization on job satisfaction, work pace and work/life balance, and autonomy of work. The items used for measuring job satisfaction were taken from Ratna \& Kaur (2016), and items used for measuring work/life balance were taken from Jääskeläinen (2015), Dimension Data (2017), and First Psychology Scotland (2015). Finally, items for measuring worker autonomy were taken from Peña-Casas, Ghailani and Coster (2018). The fifth and the sixth questions involved ranking different categories from the most important to the least important. With these two questions we wanted to determine the biggest barriers to successful adoption of new workstyles and the most important drivers of workstyle change. At the end were socio-demographic questions about gender, age, country of origin, working position, and industry.

To analyze the results of the collected responses, a one-sample t-test was implemented, conducted in the statistical software package SPSS. With it we compared the mean of each construct (which asked about the connection between digitalization and a respective factor) with the mean of its scale. We implemented a one-sample t-test to analyze all three hypotheses.

\section{RESULTS}

\subsection{Descriptive statistics}

Table 1 shows the descriptive statistics (means, standard deviations, and standard errors of the means) of the main variables. The sample consisted of 98 individuals.

Table 1: Means and standard deviations

\begin{tabular}{|l|c|c|c|c|}
\hline & N & Mean & Std. Deviation & Std. Error Mean \\
\hline Job satisfaction (H1) & 98 & 3.6268 & 0.64204 & 0.06486 \\
\hline Work/life balance (H2) & 98 & 3.39 & 1.127 & 0.114 \\
\hline Worker autonomy (H3) & 98 & 3.3010 & 0.99933 & 0.10095 \\
\hline
\end{tabular}




\subsection{Hypotheses tests}

We applied a one-sample t-test to analyze the collected data for all three hypotheses. We compared means of gathered data for each hypothesis with the midpoint of their scales - value 3 (which would represent normally distributed data) and obtained the following results. The first hypothesis ( $\mathrm{H} 1)$, "Digitalization improves job satisfaction," in which digitalization was the dependent variable and job satisfaction was the independent variable, was confirmed $(t=9.665, p=$ $0.001)$. The second hypothesis (H2), "Due to digitalization work/life balance blurs," in which digitalization was the dependent variable and work/life balance was the independent variable, also had significantly different means $(t=3.405, p=0.001)$, meaning that we confirmed that digitalization blurs work/life balance. We also confirmed our third hypothesis (H3), "Digitalization promotes more worker autonomy," in which digitalization was the dependent variable and worker autonomy was the independent variable, with statistical significance $(t=2.982, p=0.004)$.

\section{CONCLUSION AND DISCUSSION}

This paper examines the relationships between digitalization and the workplace, specifically, how digitalization affects job satisfaction, work/life balance and employee autonomy. Based on our questionnaire and analysis of the results, we found support for all three hypotheses. We confirmed our first hypothesis, which suggested that digitalization improves employees' job satisfaction. This was in line with our expectations and the results of other studies, because digitized workplaces, along with other non-wage factors, can improve employees favorable job perceptions, resulting in greater corporate efficiency (Gallie, 2013).

Furthermore, our study also confirmed our second hypothesis, which stated that digitalization blurs work/life balance. It can be stated that having access to remote work blurs work/life balance because it is usually difficult to switch off when at home. Being connected to work while at home means that an individual has less opportunity to recover from work-related efforts (Derks et al., 2014).

Lastly, we concentrated on how digitalization changes worker autonomy in the workplace. There are conflicting views among researchers regarding this topic. Some researchers are convinced that ICT promotes autonomy, whereas others believe it contributes to increased monitoring of employees. There is also evidence that digitalization can increase both autonomy and monitoring (Gerten, Beckmann \& Bellmann, 2018). We conducted this research to determine the case among Slovenian employees and avoid divergent data from other researches. The research confirmed our third hypothesis because most of the employees who participated in the research answered that the level of autonomy increased with the introduction of digitalization into their organizations. This means that higher use of technology tools in the workplace empowers Slovenian employees. The reason for this result might be the types of organizations in which employees who participated in our survey are employed. They are mostly international accounting and auditing companies, for which the use of technology tools is crucial (for meetings, correspondence with clients, for finishing different tasks, etc.). It is possible that if we conducted this research among employees of other types of organizations we would get different answers.

\subsection{Contributions and implications}

\subsubsection{Practical implications}

The results of this study are important for the owners and managers of different organizations, because it can help them understand how digitalization and technology use changes the way employees do their work. For example, our research shows that technology contributes to higher employee autonomy, which consequently means more motivation and successfully accomplished tasks. Knowing this, managers can make better decisions regarding their leadership style (for example, to empower employees with the help of ICT), which could lead to a more prosperous business.

Additionally, more significant technological altercations must be properly planned because more digitalization can in some instances result in more supervision, stress, and a significantly worse work/life balance, resulting in poorer health conditions for workers. Unions should put workers first and therefore encourage changes that make situations for them more pleasant and discourage those that have negative consequences. 
Furthermore, the results of our research can help the Slovenian government regarding the changes of work/life balance of employees which are caused by introducing ICT into organizations. It is important that they understand how digitalization affects different areas of an employee's life (for example, health, safety, etc.) in order to adopt practical solutions and new policies of reforms intended to lower the negative impact of ICT on people employed in the organizations.

Lastly, sometimes not even employees themselves pay enough attention to what digitalization brings to their professional or personal lives. By conducting this study, we wanted to emphasize more what technology use really means for employees, both its negative and positive aspects. By doing this, we wanted to inform employees more, so that they can make better decisions regarding their work styles, because they are the ones who know best what suits them and what does not.

\subsubsection{Theoretical contributions}

Firstly, when comparing our results to the results of Ratna \& Kaur (2016) similar conclusions can be drawn; i.e., implementation of new technologies results, among other things, in greater job satisfaction of employees. Moreover, Salvatori, Menon \& Zwysen (2018) discovered that technology has a positive effect on job satisfaction, similar to what our results show. Arguably, job satisfaction positively affects the mental and physical well-being of employees, quality of life, and greater society's progress, as stated by Ratna \& Kaur (2016).

Secondly, Towers et al. (2006) showed that technology offers more job flexibility, which results in giving employees the freedom to choose when and where to work. Our study showed otherwise: employees who took part in our research mostly felt that the line between their work and away-fromwork activities is blurred. Similarly, Ratna \& Kaur (2016) suggested that the use of technology in one's spare time is favorable, which is also the opposite of what our study indicated. On the other hand, other researchers have pointed out that technology might have negative consequences on work/life balance (Jääskeläinen, 2015). Working around the clock can lead to stress for an individual, and therefore to health issues. Our study has drawn a clear conclu- sion: having access to remote work while at home provokes a blurred balance between work and awayfrom-work activities. Our findings suggest that employers should be eager to reduce overtime hours, which can have negative effects on employees.

Thirdly, Aral \& Weill (2007) suggested that worker autonomy can be increased by the use of technology. For example, it can result in easier and faster communication between employees (European Economic and Social Committee, 2017). Similarly, Ardalan (2011) discovered that digitization in the workplace offers easier and more convenient access to knowledge. Our study determined that due to digitalization, employees have greater autonomy, which is in agreement with the aforementioned literature. In contrast, Gerten, Beckmann \& Bellmann (2018) pointed out that the fast expansion of technology can lead to monitoring of employees, which consequently brings less worker autonomy, which is in not in line with our findings.

Lastly, the existing data regarding autonomy and digitalization is divergent, which means that all literature on the topic is limited. By conducting our own research, we obtained clearer results regarding the Slovenian labor market and its changes provoked by digitalization. Because technology and the use of digitized gadgets in the workplace is a rapidly changing field, researchers should conduct studies of this topic frequently, especially if digitalization of the workplaces has negative effects, which should be properly dealt with.

\subsection{Limitations and future research directions}

We identified a few limitations. Firstly, the sample was rather small, which means a limited ability to conduct advanced statistical analyses. Secondly, the sample was convenient, because the survey was distributed to people who we know and are close to. The existing research could be improved by including a larger sample of employees chosen randomly. Thirdly, the survey was conducted in English, but our participants in the survey were Slovenians with limited knowledge of English. Some of them complained about a lack of understanding and the complexity of the questions. Future research could benefit from conducting the survey in Slovenian or using an adjusted level of English, which would be easier to understand. 
We also had limited access to employees in different organizations, because most of them have strict policies and sharing this type of data is forbidden. We could avoid this by including in our research those types of organizations which do not have such sensitive data and strict privacy rules. Lastly, the data collected were self-reported, which means that people reported their feelings based on their memory, which can be biased.

Future research could analyze and compare the effect of digitalization on the workplace separately for all working generations, because it is proven that younger generations have fewer problems coping with innovations in technology than do older generations. We could investigate how and why digitalization affects different generations. Additionally, it would be interesting to analyze the forecasts for the future from managers and as well as employees. We could analyze whether managers would rather "employ" robots or humans. Furthermore, it would be interesting to explore what employees think about working with robots, and if they really make work easier, or if they have hidden, not-so-positive aspects.

\section{EXTENDED SUMMARY / IZVLEČEK}

Prispevek preučuje vplive digitalizacije na delovna mesta. Digitalizacija spreminja organizacije že od odkritja interneta naprej. Dandanes je namreč poslovanje in osebno življenje brez tehnologije skoraj nepredstavljivo. Digitalizacija je za organizacije prinesla tako izzive kot priložnosti. Večina obstoječih študij se osredotoča na vplive digitalizacije na uspešnost poslovanja in produktivnost delavcev. V nasprotju z njimi ta članek preučuje vpliv digitalizacije na tri do sedaj manj raziskana področja, in sicer: zadovoljstvo pri delu, ravnotežje med delom in zasebnim življenjem ter avtonomijo zaposlenih. Avtorji predpostavljajo, da digitalizacija pozitivno vpliva na zadovoljstvo pri delu, zamegli ravnotežje med delom in zasebnim življenjem ter spodbuja večjo avtonomijo zaposlenih. Raziskava temelji na 98 odgovorih zaposlenih iz različnih panog in disciplin. Odgovori so bili zbrani s pomočjo spletne ankete. Podatki so bili analizirani s t-testi za en vzorec. S pomočjo slednjih so bile potrjene vse tri hipoteze. Ugotovitve iz raziskave lahko menedžerjem pomagajo bolje razumeti pomen in tudi same vplive digitalizacije. Ker digitalizacija na delovnem mestu prinaša izzive in tudi priložnosti, je pomembno, da jih menedžerji popolnoma razumejo; na ta način lahko odpravijo tveganja in/ali povečajo ugodne učinke.

\section{REFERENCES}

Aral, S. \& Weill, P. (2007). IT assets, organizational capabilities, and firm performance: How resource allocations and organizational differences explain performance variation. Organization Science, 18(5), pp. 763-780.

Ardalan, O. (2011). Investigating the effects of IT on employees. Case study: Kermanshah Province West Regional Electricity Distribution Company (Master Thesis). Sannandaj: Islamic Azad University of Sanandaj.

Castells, M. (2010). The rise of the network society. (Information age. economy, society and culture, 1.) Chichester, West Sussex: Wiley-Blackwell.

Chesley, N. (2010). Technology Use and Employee Assessments of Work Effectiveness, Workload, and Pace of Life. Information, Communication \& Society, 13(4), pp. 485-514.

Derks, D. \& Bakker, A.B.(2010). The Impact of E-mail Communication on Organizational Life. Cyberpsychology:
Journal of Psychosocial Research on Cyberspace. 4(1). Retrieved from: https://cyberpsychology.eu/article/view/4233/3277

Derks, D., Brummelhuhis, L., Zecic, A. \& Bakker, A. (2014). Switching on and off: Does smartphone use obstruct the possibility to engage in recovery activities? European Journal of Work and Organizational Psychology, 23(1), pp. 80-90.

Dimension Data (2017). The digital workplace report: Transforming your business. Retrieved from: https://www.dimensiondata.com/microsites//media/95C5923C59FD4437B870929D3396F891.ashx.

European Economic and Social Committee (2017). Impact of digitalisation and the on-demand economy on labour markets and the consequences for employment and industrial relations. Retrieved from: https://www.eesc.europa.eu/resources/docs/qe-0217-763-en-n.pdf?fbclid=IwAR3ogn4ADKIrUKWUwub- 
SCXcT9kwBBXkGkrmmw6MKD65Y51ZEeLeP105crus. Eurofound (2018). Automation, digitalisation and platforms: Implications for work and employment. Publications Office of the European Union, Luxembourg.

First Psychology Scotland (2015). Research Report: The Impact of Technology on Work/Life Balance. Retrieved from: https://www.firstpsychology.co.uk/files/Research-report-FULL-technology.pdf.

Gallie, D. (2013). Skills, Job Control and the Quality of Work: The Evidence from Britain. The Economic and Social Review, 43(3).

Gerten, E., Beckmann, M. \& Bellmann, L. (2018). Controlling working crowds: The impact of digitalization on worker autonomy and monitoring across hierarchical levels. Retrieved from: https://edoc.unibas.ch/61490/1/20180307130203_5a9fd4bb4605b.pdf.

Gibbs, M. (2017). How is new technology changing job design? IZA World of Labor 2017: 344.

Globocnik, D. \& Salomo, S. (2015). "Do formal management practices impact the emergence of bootlegging behavior?" Journal of Product Innovation Management, 32(4).

Governo Italiano (n.d.). The Changing World of Work. Digitalization, automation and the future of work. Italy's contribution to the ILO centenary. Retrieved from http://www.lavorochecambia.lavoro.gov.it/documenti/D ocuments/THE-CHANGING-WORLD-OF-WORK.pdf.

Hackman, J.R. \& Oldham, G.R. (1976), "Motivation through the design of work: test of a theory", Organizational Behavior and Human Performance, 16(2).

Jääskeläinen, A. (2015). Digitalization and Work Life: How new technologies are changing task content and skill demand for five selected occupations. Department of Economics Aalto University School of Business (Master's Thesis). Aalto University. Retrieved from: http://epub.lib.aalto.fi/fi/ethesis/pdf/14220/hse_eth esis_14220.pdf.

Kettunen, P. \& Laanti, M. (2017). Future software organizations - agile goals and roles. European Journal of Futures Research, 5(16).

Krause, R. (2016). Digitalisierung und Beschä ftigtendatenschutz. Forschungsbericht 482. Bundesministerium für Arbeit und Soziales.

Kuusisto M. (2015). Effects of digitalization on organizations. Master of Science thesis. Tampere university of Technology.

Lockwood, N. R. (2003). Work/Life Balance; Challenges and Solutions. SHRM Research Quarterly. Retrieved from: https://s3.amazonaws.com/academia.edu.documents/33300498/11_Lockwood_WorkLifeBalance.p df?AWSAccessKeyId=AKIAIWOWYYGZ2Y53UL3A\&EXpires $=1548535171 \&$ Signature $=Y \% 2 B b 1 c P 0 o x 9 j S J J c R-$ suYecwk6yxU\%3D\&response-content-disposition=inli
ne\%3B\%20filename\%3DWork_Life_Balance_Challenges_and_Solutio.pdf.

Lumley E. J., Coetzee M., Tladinyane R. \& Ferreira N. (2011). Exploring the job satisfaction and organisational commitment of employees in the information technology environment. Southern African Business Review, 15(1).

Maschke, M. (2016). Digitalisation: Challenges for Company Codetermination. ETUI Research Paper - Policy Brief 7/2016. Retrieved from: https://ssrn.com/abstract=2874850.

Mazid Abadi Farahani, A. (2011), Effect of Information technology to empower the employees' social security Qom (Master thesis). Tehran: Tehran University.

Peña-Casas R., Ghailani D. \& Coster S. (2018). The impact of digitalisation on job quality in European public services. The case of homecare and employment service workers. Final Report. European Social Observatory (OSE) and European Public Service Union (EPSU).

Ratna R. \& Kaur T. (2016). The impact of Information Technology on Job Related Factors like Health and Safety, Job Satisfaction, Performance, Productivity and Work Life Balance. Journal of Business \& Financial Affairs, 5(1).

Salvatori, A., S. Menon \& W. Zwysen. (2018). The effect of computer use on job quality: Evidence from Europe. OECD Social, Employment and Migration Working Papers, No. 200. OECD Publishing, Paris.

Sempane, M., Rieger, H. \& Roodt, G. (2002). Job satisfaction in relation to organisational culture. South African Journal of Industrial Psychology, 28(2), pp. 23-30.

Sullivan, O. \& Gershuny, J. (2018). Speed-Up Society? Evidence from the UK 2000 and 2015 Time Use Diary Surveys. Sociology, 52(1), pp. 20-38.

Tafti, A., Mithas, S. \& Krishnan. M.S. (2007). Increasingly, firms are using IT to exert managerial control over workers by means of detailed time tracking, proficiency assessment, and the monitoring of IT use. Retrieved from: https://terpconnect.umd.edu/ smithas/papers/taftietal2007itm.pdf.

Tage S. Kristensen, Jakob B. Bjorner, Karl B. Christensen \& Vilhelm Borg (2004). The distinction between work pace and working hours in the measurement of quantitative demands at work. Work \& Stress, 18(4), pp. 305-322.

Towers, I., Duxbury, L., Higgins. C. \& Thomas J. (2006) Time thieves and space invaders: technology, work and the organization. Journal of Organizational Change Management. 19(5), pp. 593-618.

Urbach, N. \& Röglinger, M. (2019). Introduction to Digitalization Cases: How Organizations Rethink Their Business for the Digital Age. In Digital Cases. Springer International Publishing, pp. 1-12.

Vuori, V., Helander, N. \& Okkonen J. (2018). Digitalization in knowledge work: the dream of enhanced performance. Cognition, Technology \& Work. 